\title{
PENERAPAN PENDEKATAN SUPERVISI KOLABORATIF UNTUK MENINGKATKAN KOMPETENSI PROFESIONAL GURU DI SD NEGERI 179/I LADANG PERIS
}

\section{Susanti}

SD Negri 179/I Ladang Peris

Email: susantiguru179@gmail.com

\begin{abstract}
Abstrak
Penelitian ini berjudul "Penerapan Pendekatan Supervisi Kolaboratif Untuk Meningkatkan Kompetensi Profesional Guru Di SD Negeri 179/I Ladang Peris Tahun Pelajaran 2019/2020”. Fokus kajian dalam penelitian ini adalah Perkembangan proses supervisi kolaboratif untuk meningkatkan kompetensi profesional guru di SD Negeri 179/I Ladang Peris, Sumber data berasal dari guru SD Negeri 179/I Ladang Peris yang berjumlah 9 orang guru. Teknik pengumpulan data melalui hasil tes formatif yang dilakukan. Secara garis besar penelitian ini dilakukan melalui empat tahapan dalam proses pengkajian berdaur (PTS) yaitu meliputi : perencanaan (planning), pelaksanaan (action), observasi (observation), dan refleksi (reflection). Analisis data dilakukan dengan menggunakan analisis kuantitatif dan kualitatif, selanjutnya dikonsultasikan dengan kriteria keberhasilan untuk mengetahui tuntas dan tidaknya belajar. Hasil penelitian ini adalah adanya peningkatan kompetensi profesional guru di SD Negeri 179/I Ladang Peris dari prasiklus ke siklus 1. Rata-rata kompetensi profesional guru pada pra-siklus sebesar 53,47 dengan kriteria kurang dan pada siklus 1 sebesar 70,47 dengan kriteria cukup. Kompetensi profesional guru juga mengalami peningkatan dari siklus 1 ke siklus 2. Rata-rata kompetensi profesional guru pada siklus 2 sebesar 85,47 dengan kriteria baik. Jadi, dapat disimpulkan bahwa kompetensi profesional guru di SD Negeri 179/I Ladang Peris dapat ditingkatkan melalui penerapan pendekatan supervisi kolaboratif.
\end{abstract}

Kata kunci: Supervisi, Kolaboratif, Kompetensi Profesional

\section{Pendahuluan}

Guru merupakan ujung tombak keberhasilan pendidikan. Profesionalisme seorang guru terlihat dari kompetensinya sebagai seorang guru yang terdiri dari kompetensi pedagogik, profesional, keperibadian dan sosial. Salah satu dimensi kompetensi guru sesuai dengan Peraturan Menteri Pendidikan Nasional Republik Indonesia Nomor 16 Tahun 2007 tentang Standar Kualifikasi Akademik dan Kompetensi Guru adalah kompetensi profesional. Dengan Permendiknas tersebut berarti seorang guru harus kompeten dalam melakukan kinerja profesionalnya. Kompetensi profesional guru menurut Permendiknas Nomor 16 Tahun 2007 terdiri dari kemampuan guru dalam: (1) menguasai materi, struktur, konsep, dan pola pikir keilmuan yang mendukung mata 
pelajaran yang diampu; (2) menguasai standar kompetensi dan kompetensi dasar mata pelajaran/ bidang pengembangan yang diampu; (3) mengembangkan materi pembelajaran yang diampu secara kreatif; (4) mengembangkan keprofesionalan secara berkelanjutan dengan melakukan tindakan reflektif; dan (5) memanfaatkan teknologi informasi dan komunikasi untuk berkomunikasi dan mengembangkan diri.

Efektivitas pelaksanaaan kinerja profesional guru sangat bergantung pada kompetensi kepala sekolah dalam melaksanakan tugasnya diantaranya dalam melakukan supervisi akademik. Untuk melaksanakan supervisi

akademik, kepala sekolah sebagai supervisor dan penanggungjawab kegiatan di sekolah harus mampu menyusun program, melaksanakan, dan melakukan tindak lanjut supervisi akademik di sekolah yang dipimpinnya. Pelaksanaan supervisi akademik yang baik oleh kepala sekolah akan menghasilkan kompetensi guru dalam memfasilitasi pembelajaran yang baik pula. Selanjutnya, pembelajaran yang dilaksanakan dengan baik akan berdampak pada peningkatan prestasi siswa. Dengan demikian, keberhasilan siswa dalam pembelajaran sangat bergantung pada kemampuan guru dalam memfasilitasi pembelajaran dan kompetensi kepala sekolah dalam melaksanakan supervisi akademik.

Kompetensi supervisi akademik kepala sekolah terdiri dari tiga aspek yaitu kompetensi dalam menyusun program, melaksanakan, mengevaluasi dan menindaklanjuti temuan-temuan ketika melaksanakan supervisi akademiknya. Program supervisi akademik yang harus disusun oleh seorang kepala sekolah merupakan pedoman atau acuan dalam melaksanakan supervisi akademik. Selain itu, program supervisi akademik juga dapat mengembangkan kemampuan guru dalam mengelola pembelajaran secara efektif. Dari hasil pelaksanaan supervisi akademik, kepala sekolah juga harus mampu merefleksi kinerjanya dan melaksanakan tindak lanjut sebagai umpan balik yang sangat berguna untuk peningkatan kualitas baik bagi siswa, guru, maupun dirinya yang pada akhirnya dapat meningkatkan kualitas pendidikan di sekolahnya.

Berdasarkan hasil refleksi diri yang telah dilakukan oleh peneliti sebagai kepala sekolah, selama ini kepala sekolah melaksanakan tugas supervisi akademiknya dengan menerapkan pendekatan supervisi langsung secara individual, dengan cara mendatangi guru yang sedang bertugas, mengamati kinerjanya dan melakukan penilaian. Pendekatan supervisi individual ini tidak terlalu efektif untuk meningkatkan kompetensi guru dalam melaksanakan tugasnya khususnya yang berkaitan dengan kompetensi profesionalnya. Hasil kajian empirik yang peneliti lakukan terhadap guru-guru di SD Negeri 179/I Ladang Peris menunjukkan bahwa kompetensi profesional guru masih rendah terutama pada kompetensi guru dalam mengembangkan materi pembelajaran yang diampu secara kreatif

Hasil analisis menunjukkan bahwa kompetensi guru dalam mengembangkan materi pembelajaran yang diampu masih pada kategori sedang yaitu indeks rata-rata 2,14 atau 53,47. Hasil refleksi terhadap temuan tersebut menunjukkan bahwa faktor yang menyebabkan masih rendahnya kompetensi guru tersebut diduga disebabkan oleh faktor internal dan eksternal. Faktor internal yang diduga mempengaruhi rendahya kompetensi profesional guru antara lain: Pertama, Guru belum memahami teknik pengembangan 
materi pembelajaran; Kedua, Guru tidak melakukan analisis materi pembelajaran sebelum mengembangkan bahan ajar atau materi pembelajaran; dan. Ketiga, Kurangnya motivasi diri guru untuk melakukan kinerja profesionalnya dengan baik.

Faktor eksternal yang diduga mengakibatkan rendahnya kompetensi profesional guru adalah pelaksanaan supervisi oleh kepala sekolah yang lebih bersifat menilai. Idealnya, supervisi dilaksanakan secara kolegial, tidak menggurui, bersifat kemitraan dan pendampingan, serta dilakukan melalui diskusi dan curah pendapat secara terbuka dan fleksibel untuk membantu guru merefleksi kinerjanya dalam melaksanakan tugas profesionalnya. Salah satu pendekatan yang mengedepankan kemitraan atau rekan kerja antara kepala sekolah sebagai supervisor akademik dan guru sebagai orang yang disupervisi, lebih bersifat mendampingi melalui diskusi dan curah pendapat secara terbuka dan fleksibel serta memiliki tujuan yang jelas untuk membantu guru berkembang menjadi tenaga-tenaga profesional melalui kegiatan-kegiatan reflektif adalah pendekatan supervisi kolaboratif.

\section{Metode Penelitian}

Metode penelitian yang digunakan pada penelitian ini adalah metode Penelitian Tindakan Sekolah (PTS) dengan model Kemmis dan Mc. Taggart yang merupakan model pengembangan dari model Kurt Lewin. Dikatakan demikian, karena di dalam suatu siklus terdiri atas empat komponen, keempat komponen tersebut, meliputi: (1) perencanaan, (2) aksi/ tindakan, (3) observasi, dan (4) refleksi. Setelah suatu siklus selesai diimplementasikan, khususnya sesudah adanya refleksi, kemudian diikuti dengan adanya perencanaan ulang yang dilaksanakan dalam bentuk siklus tersendiri.

Analisis data dilakukan secara kuantitatif dan kualitatif. Teknik pengolahan data secara kuantitatif dilakukan terhadap variabel kompetensi profesional guru. Data yang diperoleh dari hasil pengamatan atau observasi kinerja profesional guru dalam mengembangkan materi pembelajaran yang terdiri dari empat aspek yaitu keterurutan, keberjenjangan, kedalaman, dan keluasan diolah dengan menentukan nilai rata-ratanya. Analisis data kompetensi profesional guru dilakukan menggunakan prosentase (\%), yakni perhitungan yang digunakan untuk mengetahui tingkat prosentase skor penilaian dari masing-masing indikator kompetensi profesional guru dalam mengembangkan materi pembelajaran. Rumus yang digunakan adalah sebagai berikut:

Prosentase $(\%)=\left(\sum \mathrm{n}\right) / \mathrm{N} X 100 \%$

Dimana:

$\sum \mathrm{n}=$ Jumlah skor jawaban responden

$\mathrm{N}=$ Jumlah skor jawaban ideal

$\%=$ Tingkat persentase

Teknik pengolahan data kualitatif dilakukan terhadap variabel proses supervisi kolaboratif yang dikumpulkan melalui lembar observasi proses supervisi kolaboratif yang diolah dengan cara mengkategorikan dan mengklasifikasikan data berdasarkan analisis kaitan logis, kemudian ditafsirkan dalam konteks permasalahan penelitian. Kegiatan ini berupaya memunculkan makna dari setiap data yang didapat, sehingga data itu tidak 
hanya bersifat deskriptif. Dalam penelitian dengan pendekatan kualitatif, pengolahan dan analisis data dilakukan secara terus-menerus dari awal sampai akhir pelaksanaan program Tindakan.

\section{Hasil dan Pembahasan}

\section{A. Proses Supervisi Kolaboratif pada Siklus 1}

Supervisi kolaboratif pada siklus 1 ini dilaksanakan pada tanggal 3 Februari s.d. 15 Februari 2020. Pendekatan supervisi kolaboratif pada siklus 1 dilaksanakan dengan menerapkan kesepuluh prinsip pendekatan supervisi kolaboratif yaitu prinsip kolaboratif, kolegial, kemitraan, terbuka dan fleksibel. Temuan-temuan selama proses supervisi kolaboratif berlangsung dikumpulkan menggunakan lembar observasi proses supervisi kolaboratif dan catatan lapangan. Peneliti sebagai observer mengamati keterlaksanaan supervisi dengan menerapkan pendekatan supervisi kolaboratif yang selanjutnya memberikan deskripsi pada kolom yang telah disediakan pada lembar observasi proses supervisi kolaboratif.

Pada siklus 1 ditemukan beberapa temuan pada tahap spesifik kegiatan supervisi kepala sekolah dengan menerapkan pendekatan supervisi kolaboratifHasil refleksi pada siklus 1 yang telah dilakukan menunjukkan beberapa hal sebagai berikut:

Pertama, Seluruh guru tidak membawa daftar masalah terkait kompetensi profesionalnya dalam mengembangkan materi pembelajaran dan bahan ajar sehingga curah pendapat dan diskusi pada tahap Pra-Supervisi Kolaboratif tidak berjalan dengan baik dibuktikan dengan hanya satu orang guru berkode G09 yang aktif mencurahkan pendapatnya. Temuan ini diduga disebabkan oleh kepala sekolah yang tidak melakukan koordinasi dengan guru untuk mengidentifikasi masalah-masalah krusial pada saat melakukan kinerja profesionalnya dalam mengembangkan materi pembelajaran dan bahan ajar, mencatat dan membawanya pada saat curah pendapat dan diskusi dilakukan (tahap Pra-Supervisi Kolaboratif). Hal ini bertentangan dengan pendapat Glickman (1984) yang menyatakan bahwa tugas supervisi oleh kepala sekolah dalam supervisi kolaboratif adalah mendengarkan dan memperhatikan secara cermat keluhan guru terhadap masalah perbaikan, peningkatan, dan pengembangan kinerjanya. Dalam pendekatan supervisi kolaboratif, kepala sekolah dapat meminta penjelasan guru terhadap hal-hal yang kurang dipahaminya. Selanjutnya, kepala sekolah mendorong guru untuk mengaktualisasikan pemikiran bersama dalam praktik nyata pemecahan masalah yang berkaitan dengan tugas profesional guru. Dikarenakan pada tahapan ini guru tidak melakukan identifikasi masalah-masalah ketika melaksanakan kinerja profesionalnya dalam mengembangkan materi pembelajaran dan bahan ajar, tidak mencatat dan membawanya pada kegiatan pra-supervisi kolaboratif, sehingga bahan untuk diskusi dan curah pendapat sangat kurang dan tidak terfokus. Hal ini menyebabkan curah pendapat dan diskusi tidak dapat berjalan dengan baik, sehingga tahap Pra-Supervisi Kolaboratif tidak dapat dilaksanakan secara efektif. Adapun guru yang berkode G09 aktif mencurahkan pendapatnya tetapi masalah yang disampaikannya tidak terfokus pada kompetensi profesional terkait pengembangan materi pembelajaran dan bahan ajar. 
Berdasarkan hasil analisis data di atas, sebelum melakukan kegiatan supervisi kolaboratif khususnya pada tahap Pra-Supervisi Kolaboratif, kepala sekolah terlebih dahulu melakukan koordinasi dengan semua guru dan menjelaskan teknis supervisi kolaboratif yang akan dilaksanakan diantaranya mengindentifikasi masalah-masalah krusial ketika melaksanakan kinerja profesionalnya, mencatat dan membawanya pada saat curah pendapat dan diskusi bersama kepala sekolah dan guru lainnya.

Kedua, terdapat dua orang guru dengan kode G07 dan G09 yang tidak menyiapkan hasil analisis materi pembelajaran ketika supervisi kolaboratif dilakukan di sekolah sehingga pelaksanaan supervisi kolaboratif menjadi terganggu. Segiovanni (1987) menyatakan bahwa penilaian kinerja guru dalam mengembangkan materi pembelajaran dan bahan ajar tidak terlepas dari hasil analisis materi pembelajaran yang telah disusunnya. Menurutnya, menilai unjuk kerja guru dalam mengembangkan materi pembelajaran dan bahan ajar merupakan salah satu kegiatan yang tidak bisa dihindarkan dari prosesnya. Kegiatan penilaian kinerja guru dalam mengembangkan materi pembelajaran dan bahan ajar dilakukan terhadap hasil analisis materi pembelajaran yang sebelumnya harus disiapkan oleh guru sebelum melaksanakan kinerja profesionalnya dalam mengembangkan materi pembelajaran dan bahan ajar. Nolan (2011) menyatakan bahwa supervisi akademik dapat berjalan dengan baik jika guru menyiapkan perlengkapan dan instrumen yang dibutuhkan. Instrumen supervisi akademik yang tidak disiapkan oleh guru dikarenakan pada tahap pra-supervisi kolaboratif, kepala sekolah tidak menegaskan atau menguatkan bahwa pada tahap supervisi kolaboratif, guru harus menyiapkan perlengkapan dan instrumen supervisi akademik. Berdasarkan hasil analisis data di atas, sebelum melakukan kegiatan supervisi kolaboratif, kepala sekolah seharusnya menguatkan dan menegaskan kepada guru untuk menyiapkan kelengkapan diantaranya instrumen supervisi akademik pada tahap pra-supervisi kolaboratif

\section{B. Proses Supervisi Kolaboratif pada Siklus 2}

Supervisi kolaboratif pada siklus 2 ini dilaksanakan pada tanggal 17 s.d. 29 Februari 2020. Pendekatan supervisi kolaboratif pada siklus 2 dilaksanakan berdasarkan rekomendasi-rekomendasi pada siklus 1 dengan menerapkan kesepuluh prinsip pendekatan supervisi kolaboratif yaitu prinsip kolaboratif, kolegial, kemitraan, terbuka dan fleksibel.

Pada siklus 2 ini tidak ditemukan lagi temuan-temuan negatif, dan pelaksanaan supervisi kolaboratif sudah sesuai dengan tahapan-tahapan spesifik supervisi kolaboratif. Temuan-temuan positif pada tahap spesifik supervisi dengan menerapkan pendekatan supervisi kolaboratif. Hasil refleksi pada siklus 2 yang telah dilakukan menunjukkan beberapa hal sebagai berikut:

Pertama, curah pendapat dan diskusi berjalan dengan baik dan seluruh guru aktif berdiskusi dan mencurahkan pendapatnya dikarenakan pada tahap pra-supervisi kolaboratif, kepala sekolah terlebih dahulu melakukan koordinasi dengan semua guru dan menjelaskan teknis supervisi kolaboratif yang akan dilaksanakan diantaranya mengindentifikasi masalah-masalah krusial ketika melaksanakan kinerja profesionalnya, 
mencatat dan membawanya pada saat curah pendapat dan diskusi bersama kepala sekolah dan guru lainnya.

Kedua, Pelaksanaan supervisi kolaboratif berjalan dengan efektif dan guru mampu menerapkan solusi-solusi dari masalah yang teridentifikasi sebelumnya sebagai hasil curah pendapat dan diskusi dengan guru lain dan kepala sekolah pada tahap pra-supervisi kolaboratif. Hal ini dikarenakan bahwa proses supervisi kolaboratif telah menerapkan prinsip-prinsipnya yaitu kolaboratif, kolegial, kemitraan, terbuka dan fleksibel. Selain itu, Pada akhir tahap pra-supervisi kolaboratif, kepala sekolah menguatkan dan menegaskan kepada guru untuk menyiapkan kelengkapan dalam melaksanakan kinerja profesionalnya berupa hasil analisis materi pembelajaran.

Ketiga, Seluruh guru terlibat dalam proses refleksi pada tahap pasca-supervisi kolaboratif dikarenakan kepala sekolah telah koordinatif dengan guru dan telah berhasil memotivasi guru untuk saling belajar

\section{Kompetensi Profesional Guru pada Siklus 1}

Kompetensi profesional guru ini terdiri dari kemampuannya dalam mengembangkan materi pembelajaran dan bahan ajar. Kompetensi guru dalam melaksanakan kinerja profesionalnya diamati dan diukur menggunakan lembar observasi kinerja profesional guru dalam mengembangkan materi pembelajaran dan bahan ajar. Berikut merupakan rata-rata kompetensi profesional guru di SD Negeri179/I Ladang Peris yang diukur dan diamati terhadap 9 guru.

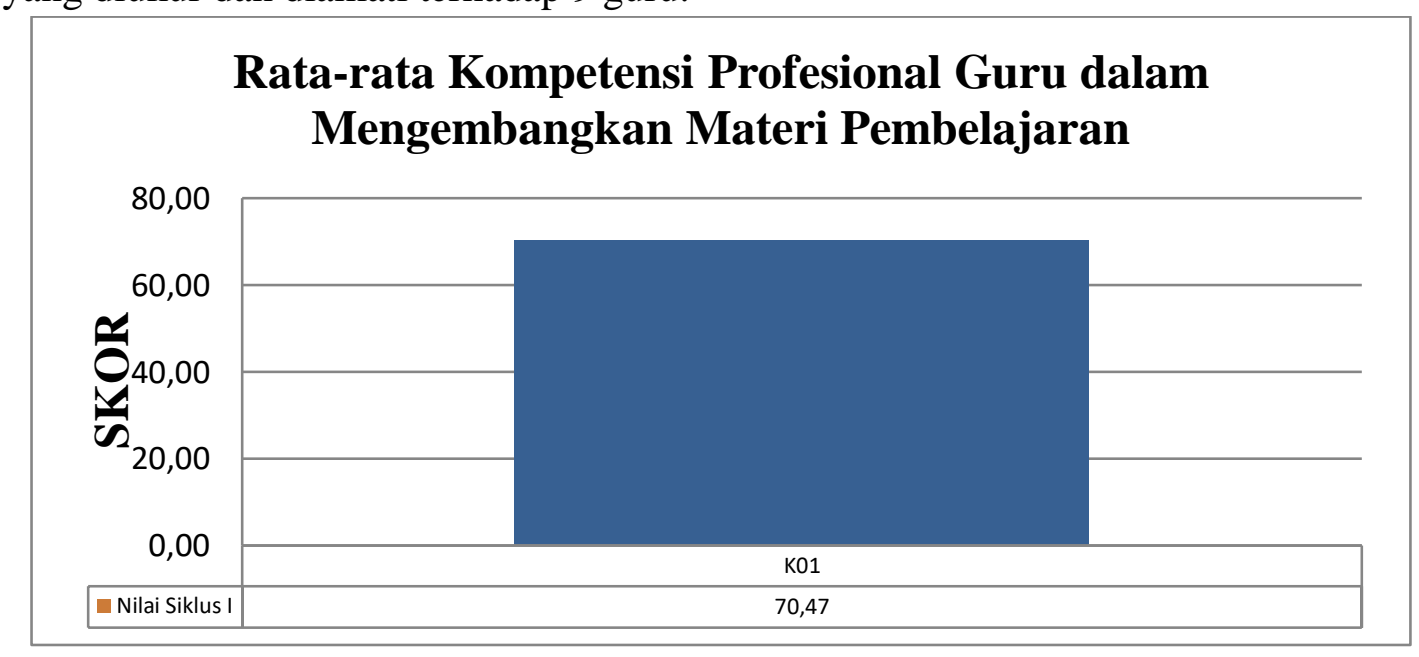

Grafik 1. Rata-rata Kompetensi Profesional Guru dalam Mengembangkan Materi Pembelajaran pada Siklus 1

Pada Grafik 1. di atas terlihat skor rata-rata kompetensi profesional guru dalam mengembangkan materi pembelajaran dan bahan ajar sebesar 70,47 dengan kriteria cukup. Hal ini menunjukkan bahwa kemampuan guru dalam mengembangkan materi pembelajaran dan bahan ajar setelah diterapkan pendekatan supervisi kolaboratif sudah cukup baik. Berbeda dengan sebelum diterapkan pendekatan supervisi kolaboratif, ratarata kompetensi guru dalam mengembangkan materi pembelajaran dan bahan ajar sebesar 
53,47 dengan kriteria kurang. Hal ini menunjukkan bahwa pendekatan supervisi kolaboratif dapat meningkatkan kompetensi profesional guru dalam mengembangkan materi pembelajaran dan bahan ajar.

\section{Kompetensi Profesional Guru pada Siklus 2}

Seperti halnya pada siklus 1, Kompetensi profesional guru yang diukur adalah kemampuan guru dalam mengembangkan materi pembelajaran dan bahan ajar. Kompetensi profesional guru ini diamati dan diukur menggunakan lembar observasi kinerja profesional guru dalam mengembangkan materi pembelajaran dan bahan ajar. Berikut merupakan rata-rata kompetensi profesional guru di SD Negeri 179/I Ladang Peris yang diukur dan diamati terhadap 9 guru.

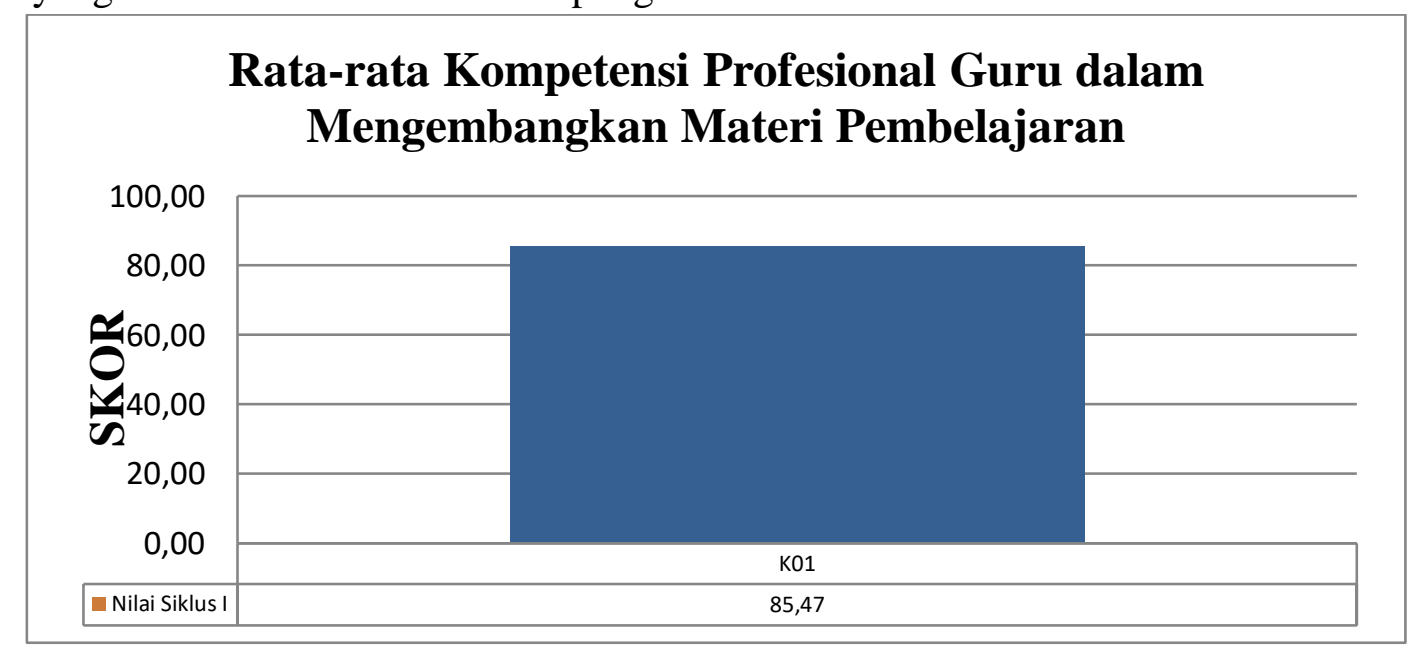

Grafik 2. Rata-rata Kompetensi Profesional Guru dalam Mengembangkan Materi Pembelajaran pada Siklus 2

Pada Grafik 2. di atas terlihat bahwa skor rata-rata kompetensi profesional guru dalam mengembangkan materi pembelajaran dan bahan ajar sebesar 85,47 dengan kriteria baik. Hal ini menunjukkan bahwa kemampuan guru dalam mengembangkan materi pembelajaran dan bahan ajar pada siklus 2 setelah diterapkan pendekatan supervisi kolaboratif sudah baik. Berbeda dengan siklus 1, rata-rata kompetensi profesional guru dalam mengembangkan materi pembelajaran dan bahan ajar sebesar 70,47 dengan kriteria cukup baik. Hal ini menunjukkan bahwa pendekatan supervisi kolaboratif dapat meningkatkan kompetensi profesional guru dalam mengembangkan materi pembelajaran dan bahan ajar.

Kompetensi profesional guru mengalami peningkatan dari pra-siklus, siklus 1 sampai dengan siklus 2. Tabel 4.5 dan Grafik 4.7 berikut merupakan peningkatan kompetensi profesional guru dari sebelum dilakukan tindakan (pra-siklus) sampai dengan setelah diterapkan tindakan berupa pendekatan supervisi kolaboratif (siklus 1 dan 2).

\begin{tabular}{cccc}
\hline Kompetensi & Pra-siklus & Siklus 1 & Siklus 2 \\
\hline Rata-rata & 53,47 & 70,47 & 85,47 \\
\hline
\end{tabular}




\begin{tabular}{llll}
\hline Kriteria & Kurang & Cukup & Baik \\
\hline
\end{tabular}

Tabel 1. Peningkatan Kompetensi Profesional Guru

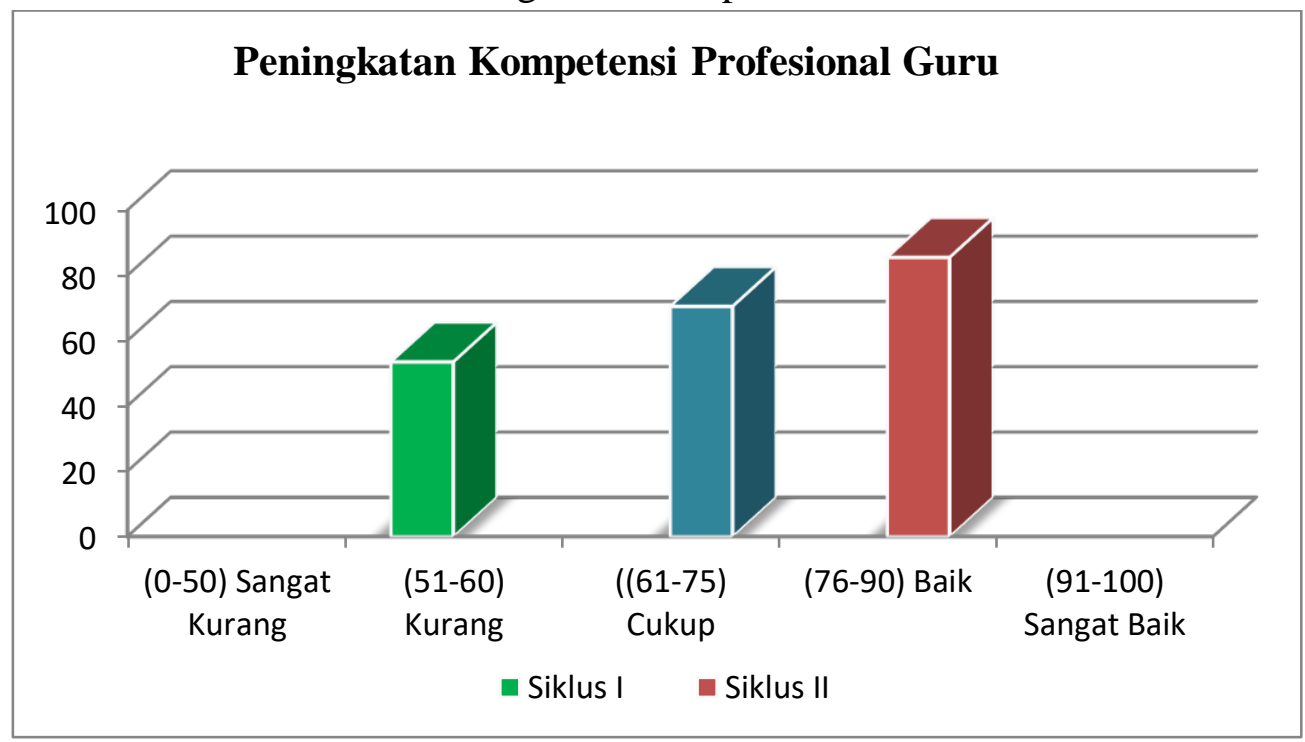

Grafik 3. Peningkatan Kompetensi Profesional Guru

Tabel 1 dan Grafik 3 di atas menunjukkan bahwa kompetensi profesional guru mengalami peningkatan dari pra-siklus ke siklus 1 dan dari siklus 1 ke siklus 2 . Hal ini diduga bahwa pendekatan supervisi kolaboratif telah dilaksanakan secara efektif selamat proses supervisi baik pada tahap pra-, pelaksanaan, dan pasca-supervisi kolaboratif.

\section{Kesimpulan}

Pada penelitian yang telah dilakukan, maka dapat disimpulkan bahwa ada beberapa hasil: Pertama,. Proses supervisi dengan menerapkan pendekatan supervisi kolaboratif secara spesifik terdiri dari tahap pra-supervisi kolaboratif, supervisi kolaboratif dan pasca-supervisi kolaboratif. Proses supervisi dengan menerapkan pendekatan supervisi kolaboratif mengalami perkembangan dari siklus 1 ke siklus 2. Pada tahap pra-supervisi kolaboratif siklus 1, curah pendapat tidak berjalan dengan efektif karena kepala sekolah tidak melakukan koordinasi dengan semua guru dan tidak menjelaskan teknis supervisi kolaboratif yang akan dilaksanakan diantaranya mengindentifikasi masalah-masalah krusial ketika guru melaksanakan kinerja profesionalnya, mencatat dan membawanya pada saat curah pendapat dan diskusi bersama kepala sekolah dan guru lainnya. Kemudian pada siklus 2, kepala sekolah melakukan koordinasi dengan semua guru dan menjelaskan teknis supervisi kolaboratif yang akan dilaksanakan serta menguatkan dan menegaskan kepada guru untuk menyiapkan kelengkapan terkait kinerja profesionalnya sehingga curah pendapat dan diskusi. Kedua, berjalan dengan tertib dan efektif. Pada tahap supervisi kolaboratif siklus 1, proses supervisi kolaboratif terhambat karena guru tidak membawa kelengkapan terkait kinerja profesionalnya, sedangkan pada siklus 2 mereka 
membawa semua kelengkapan sehingga pelaksanaan supervisi kolaboratif berjalan dengan tertib. Pada tahap pasca-supervisi kolaboratif, kepala sekolah tidak koordinatif dengan semua guru dan tidak berhasil memotivasi guru untuk saling belajar. Sedangkan pada siklus 2, kepala sekolah mulai koordinatif dengan semua dan berhasil memotivasi guru untuk saling belajar. Ketiga, Peningkatan kompetensi profesional guru di SD Negeri 179/I Ladang Peris dari pra-siklus ke siklus 1. Rata-rata kompetensi profesional guru pada pra-siklus sebesar 53,47 dengan kriteria kurang dan pada siklus 1 sebesar 70,47 dengan kriteria cukup. Kompetensi profesional guru juga mengalami peningkatan dari siklus 1 ke siklus 2. Rata-rata kompetensi profesional guru pada siklus 2 sebesar 85,47 dengan kriteria baik. Jadi, dapat disimpulkan bahwa kompetensi profesional guru di SD Negeri 179/I Ladang Peris dapat ditingkatkan melalui penerapan pendekatan supervisi kolaboratif. 


\section{Bibliografi}

Alfonso, RJ., Firth, G.R., dan Neville, R.F.2001. Instructional Supervision, A Behavior System, Boston: Allyn and Bacon, Inc.

Ali Mohamad, 2007, Pengantar Statistik, Bandung.

Danim, Sudarwan. 2006. Visi Baru Manajemen Sekolah. Jakarta: Bumi Aksara.

Departemen Pendidikan dan Kebudayaan RI. 2002. Alat Penilaian Kemampuan Guru: Buku I. Jakarta: Proyek Pengembangan Pendidikan Guru.

Direktorat Tenaga Pendidik - Dirjen PMPTK - Depdiknas RI, 2007, Supervisi Akademik dalam Peningkatan Profesionalisme Guru, Jakarta.

Direktorat Tenaga Pendidik - Dirjen PMPTK - Depdiknas RI, 2008, Metode dan Teknik Supervisi, Jakarta.

Direktorat Pembinaan Pendidik dan Tenaga Kependidikan Pendidikan Dasar - Direktorat Jenderal Pendidikan Dasar Kementerian Pendidikan dan Kebudayaan, 2014, Supervisi Pembelajaran - Bahan Materi Bimbingan Teknis Penguatan Kepala Sekolah, Jakarta.

Glickman, C.D 1995. Supervision of Instruction. Boston: Allyn And Bacon Inc.

Gwynn, J.M. 1961. Theory and Practice of Supervision. New York: Dodd, Mead \& Company.

McPherson, R.B., Crowson, R.L., \& Pitner, N.J. 2006. Managing Uncertainty: Administrative Theory and Practice in Education. Columbus, Ohio: Charles E. Merrill Pub. Co.

Nolan, J.F. 2011. Teacher Supervision and Evaluation. Wiley: United State of America.

Oliva, Peter F. 2004. Supervision For Today’s School. New York: Longman.

Peraturan Menteri Pendidikan Nasional No. 13 tahun 2007 tentang Standar Kompetensi Kepala Sekolah/Madrasah, Jakarta.

Peraturan Menteri Pendidikan Nasional No. 41 tahun 2007 tentang Standar Proses Jakarta.

Pidarta, Made. 1992. Pemikiran Tentang Supervisi Pendidikan. Jakarta: Bumi Aksara.

Purwadarminta, 2003, Kamus Umum Bahasa Indonesia, Balai Pustaka Jakata.

Purwanto, Ngalim.2003. Administrasi dan Supervisi Pendidikan. Bandung: Rosdakarya 
Pusat Pengembangan Tenaga Kependidikan - Badan PSDMP \& K dan PMP Kementerian Pendidikan dan Kebudayaan, 2012, Supervisi Akademik - Bahan Pembelajaran Utama - Pengembangan Keprofesian Berkelanjutan Tingkat I Kepala Sekolah Dasar/Madrasah Ibtidaiyah. Jakarta

Sergiovanni, T.J. 2002. Editor. Supervision of Teaching. Alexandria: Association for Supervision and Curriculum Development.

Sergiovanni, T.J. 2007. The Principalship, A Reflective Practice Perspective. Boston: Allyn and Bacon.

Sergiovanni, T.J. dan R.J. Starrat. 1979. Supervision: Human Perspective. New York: McGraw-Hill Book Company.

Setya AP, 12 Februari 2012, Supervisi Pendidikan, FIP - UNY 